Ghashut, R. A., Blackwell, S., Ryan, S., Willox, L., McMillan, D. C., Kinsella, J. and Talwar, D. (2017) Assessment of asymmetrical dimethylarginine metabolism in patients with critical illness. European Journal of Clinical Investigation, 47(4), pp. 279-288. There may be differences between this version and the published version. You are advised to consult the publisher's version if you wish to cite from it.

Ghashut, R. A., Blackwell, S., Ryan, S., Willox, L., McMillan, D. C., Kinsella, J. and Talwar, D. (2017) Assessment of asymmetrical dimethylarginine metabolism in patients with critical illness. European Journal of Clinical Investigation, 47(4), pp. 279-

288. (doi:10.1111/eci.12710) This article may be used for non-commercial purposes in accordance with Wiley Terms and Conditions for SelfArchiving.

http://eprints.gla.ac.uk/132978/

Deposited on: 07 February 2017

Enlighten - Research publications by members of the University of Glasgow http://eprints.gla.ac.uk 
Received Date : 11-May-2016

Revised Date : 01-Nov-2016

Accepted Date : 01-Dec-2016

Article type : Original Paper

\section{Assessment of Asymmetrical Dimethylarginine metabolism in Patients with Critical Illness.}

Rawia A Ghashut ${ }^{12}$, Scott Blackwell ${ }^{3}$, Sylvia Ryan ${ }^{3}$, Laura Willox ${ }^{3}$, Donald C McMillan ${ }^{2}$, John Kinsella ${ }^{1}$, Dinesh Talwar ${ }^{3}$

1. Academic Unit of Anaesthesia, College of Medical, Veterinary and Life of Sciences- University of Glasgow, Royal Infirmary, Glasgow G31 2ER.

2. Academic Unit of Surgery, College of Medical, Veterinary and Life of Sciences- University of Glasgow, Royal Infirmary, Glasgow G31 2ER.

3. The Scottish Trace Element and Micronutrient Reference Laboratory, Department of Biochemistry, Royal Infirmary, Glasgow G31 2ER

Short title: Asymmetrical Dimethylarginine in critical illness.

\section{Correspondence to;}

Rawia Ghashut

Academic unit of Anaesthesia College of Medical, Veterinary and Life of Sciences- University of Glasgow, Royal Infirmary, Glasgow G31 2ER, United Kingdom.

Tel No. 01412118647

Fax No. 01412111191

Email: rgashot@yahoo.co.uk

This article has been accepted for publication and undergone full peer review but has not been through the copyediting, typesetting, pagination and proofreading process, which may lead to differences between this version and the Version of Record. Please cite this article as doi: $10.1111 /$ eci.12710

This article is protected by copyright. All rights reserved. 


\section{Abstract}

Background: Critically ill patients experience metabolic disorders including hypercatabolic state and hyperglycaemia and these are associated with poor outcome. Hyperglycaemia and asymmetric dimethylarginine (ADMA) are reported to have significant influences on endothelial dysfunction. The aim of the present study was to examine the relationship between plasma asymmetric dimethylarginine (ADMA) and related arginine metabolism in patients with critical illness.

Materials and Methods: Two venous blood samples (EDTA) (104 patients), on admission and follow up sample in the last day in ICU (died or discharge sample median 7, IQR 6-8, range 5-15). Plasma ADMA, arginine, homoarginine and symmetrical dimethylarginine (SDMA) were measured by highperformance liquid chromatography (HPLC).

Result: ADMA $(p<0.01)$ and SDMA $(p<0.05)$ were elevated and homoarginine was decreased $(p<0.05)$ in non-survivors and were directly associated with predicted mortality rate $(p<0.05$ and $p<0.001)$, SOFA $(p<0.05, p<0.001)$, ICU stay $(p<0.05, p<0.001)$ and mortality $(p<0.01, p<0.05)$. ADMA was directly associated with SDMA $(p<0.001)$, albumin $(p<0.05)$, ICU stay and mortality $(p<0.01)$. SDMA was directly associated with creatinine $(p<0.001)$ and APACHE II score $(p<0.001)$. In the follow up measurements there was a significant decrease in SOFA score $(p<0.01)$, homoarginine $(p<0.01)$, ALT $(p<0.01)$, Lab-Glucose $(p<0.01)$, and albumin $(p<0.01)$. In contrast, there was an increase in arginine $((p<0.01), \operatorname{ADMA}(p<0.01), \mathrm{ADMA}: \mathrm{SDMA}$ ratio $(p<0.01)$, and the norepinephrine administration $(p<0.01)$.

Conclusion: In the present longitudinal study ADMA metabolism was altered in patients with critical illness and was associated with disease severity and mortality.

Key words: Homoarginine; arginine; asymmetric dimethylarginine; symmetrical dimethylarginine; critical illness.

\section{Key messages:}

1. The significant elevation of ADMA and SDMA in patients with critical illness were directly associated with disease severity and mortality.

2. Plasma homoarginine concentrations were significantly inversely associated with C-reactive protein suggesting an effect of inflammation on homoarginine synthesis and/or metabolism.

3. Plasma homoarginine concentrations were lower in patients with critical illness and were also associated with disease severity and mortality.

\section{Introduction}

Patients with critical illness are often hypercatabolic and hyperglycaemic, and these metabolic disorders have been shown to have a significant influence on patient outcome $[1 ; 2]$. Furthermore, several studies have reported a beneficial effect of controlling hyperglycaemia on morbidity and mortality [1;3]. However, the mechanisms by which these beneficial effects are brought about remain unclear. One possible mechanism is the amelioration of endothelial dysfunction related to endogenous nitric oxide synthase (NOS) inhibitors $[1 ; 4 ; 5]$.

This article is protected by copyright. All rights reserved. 
Endothelial dysfunction has been reported in association with insulin resistance and increased concentrations of the NOS inhibitor asymmetric dimethylarginine (ADMA) which may lead to a reduction in the bioavailability of nitric oxide (NO) (Figure 1) [6;7]. ADMA has been implicated in the endothelial dysfunction accompanying a broad range of clinical disorders such as obesity, cardiovascular disease, chronic renal failure, diabetes and hypertension [7-9]. Indeed, a significant increase in plasma ADMA concentration has been reported in individuals with impaired glucose tolerance [10], diabetes [11] and in the overweight, in whom weight loss was associated with a reduction in ADMA and improved markers of insulin sensitivity [10]. It is of interest that, in patients with acute illness, increased ADMA concentration has been associated with increased mortality and several studies have reported ADMA concentration as an independent risk factor for adverse outcomes in patients with critical illness. For example, in the intensive care unit (ICU) and in severe sepsis $[1 ; 12-14]$ and in patients presenting to the emergency department [15]. Siroen reported that there was a significant reduction in ADMA concentrations in critically ill patients who received intensive insulin treatments compared with patients who were treated conventionally [1]. This reduction was associated with a significant improvement in mortality [1;4]. In the critically ill patients higher concentrations of ADMA have been associated with increased mortality [10]. Furthermore improved outcomes have been reported with intensive insulin therapy, with amelioration of high ADMA concentrations a possible mechanism for this beneficial effect $[1 ; 4]$, possibly through preservation of dimethylaminohydrolase (DDAH) activity, the key enzyme involved in ADMA degradation. Moreover, insulin may decrease the degradation of arginine and thereby reduce the production of ADMA [16]. In contrast, however, lapichino (2008) reported that intensive insulin treatments, while achieving tight glucose control, did not reduce ADMA levels in patients with septic shock who were fed with no more than $25 \mathrm{kCal} / \mathrm{kg}$ per day [17].

It has been reported during acute inflammatory response of elective surgery plasma ADMA concentration decreases rapidly in the first 48 hours [18]. It has also been shown that inflammatory markers, such as interleukin-6 (IL-6), C-reactive protein (CRP) and tumour necrosis factor $\alpha$ are inversely associated with ADMA concentrations and the ADMA:SDMA ratio, and this has been proposed to be the result of increased (DDAH-mediated) catabolism induced by an inflammatory response [13].

The aim of the present study was to examine the relationships between the concentrations of plasma ADMA and related compounds (homoarginine, arginine, SDMA), length of stay and mortality in patients with critical illness.

\section{Methods}

\section{Patients and study design}

Patients in the intensive care unit (ICU) of the Royal Infirmary, Glasgow who were $\geq 18$ years old, and had evidence of the systemic inflammatory response syndrome as per 1992 consensus criteria $[19,20]$ were studied. There were no other exclusion criteria. The study was approved by the ethics committees of the North Glasgow NHS Trust and Multicentre Research Ethics Committee (MREC) Scotland. Where patients were unable to give signed informed consent, consent was obtained from the patients' next of kin or welfare guardian in accordance with the requirements of

This article is protected by copyright. All rights reserved. 
the Adults with Incapacity Scotland (2000) Act.

Blood samples for population references values were obtained from laboratory staff, from local health centres and from people attending a cardiovascular risk clinic. None of the subjects were taking any vitamin supplements or had evidence of a systemic inflammatory response (serum C-reactive protein $<10 \mathrm{mg} /$ I).

\section{Data collection.}

Baseline demographics including age, ICU admission cause, and ICU length of stay were extracted from ICU computer using Carevue programme. Such data was collected as part of routine clinical care including laboratory blood glucose, C-reactive protein (CRP), white cell count, albumin, creatinine, alanine aminotransferase (ALT) and liver function tests. Drugs and their dosages that may have influenced blood glucose were also recorded such as insulin, epinephrine, norepinephrine, dobutamine and hydrocortisone. APACHE II score and predicted hospital mortality and SOFA scores were recorded.

\section{ICU insulin protocol}

The blood glucose concentration were targeted at 4.4-6.9 mmol/l $(80-124 \mathrm{mg} / \mathrm{dl})$ using a standardised insulin infusion protocol using insulin infusion with a concentration of 50 units of insulin in $50 \mathrm{ml} 0.9 \%$ saline.

There were several enteral feeding preparations used in the ICU such as Jevity $(1 \mathrm{Kcal} / \mathrm{ml})$, Jevity Plus $(1.2 \mathrm{Kcal} / \mathrm{ml})$, Jevity $1.5(1.5 \mathrm{Kcal} / \mathrm{ml})$ and Osmolite $(1 \mathrm{Kcal} / \mathrm{ml})$, Osmolite Plus $(1.2$ $\mathrm{Kcal} / \mathrm{ml})$, Peptisorb $(1 \mathrm{Kcal} / \mathrm{ml})$, Perative $(1.31 \mathrm{Kcal} / \mathrm{ml})$ and Nepro $(2 \mathrm{Kcal} / \mathrm{ml})$. Patients routinely received $2 \mathrm{~L}$ of one of these preparations per day, amounting to an intake of 2000-2500 calories per day.

\section{Analytical methods}

\section{Collection and preparation of blood samples.}

Venous blood samples (EDTA) were withdrawn on admission (day 1 ) as well as a follow up sample on the last day of the ICU admission whether the patient died or was discharged (median 7, IQR 6-8, range 5-15 days) for the analysis of plasma ADMA, arginine, homoarginine and SDMA. Blood samples were centrifuged ( $500 \mathrm{~g}, 10$ minutes), the plasma removed and stored at $-70^{\circ} \mathrm{C}$ until analysis. Blood samples that formed part of patients' clinical care were handled in the usual way according to established standard operating procedures in the hospital biochemistry laboratory.

\section{Laboratory analysis}

ADMA, arginine, homoarginine and SDMA were measured using isocratic high performance liquid chromatography (HPLC) with fluorescence detection as previously described [21]. The coefficients of variation (CV) were approximately $3 \%$ for the analytes. Reference values for the studied analytes were derived from 86 healthy people [21]. In the present study the control group

This article is protected by copyright. All rights reserved. 
was not age and sex matched to the ICU patients rather they were to provide a "normal" reference range for the analytes measured in the patients with critical illness.

Blood glucose, CRP, white cell count, albumin, creatinine and alanine aminotransferase (ALT) were measured in accordance with the manufacturer's instructions on an automated analyzer (Architect; Abbott Diagnostics, Abbott Park, Chicago, IL) in the routine accredited biochemistry laboratory (Clinical Pathology Accreditation UK). For CRP, the limit of detection was $0.5 \mathrm{mg} / \mathrm{L}$. The interassay $\mathrm{CV}$ was $<5 \%$ over the sample concentration range for all of the analytes measured.

\section{Statistical analysis}

As the data was not normally distributed it was presented as median (median, IQR) and non parametric testing used as appropriate. The relationship between patient characteristics and plasma arginine, homoarginine ADMA and SDMA concentrations were carried out with the use of the MannWhitney $U$ test. Correlations between variables in the control and critically-ill groups were carried out using the Spearman rank correlation. Data from different time points in the patient groups were tested for statistical significance with the use of the Wilcoxon signed rank test. Due to the number of unpaired and paired statistical comparisons carried out a $P$ value of $<0.01$ was considered to be significant. With reference to ICU mortality data were analysed by univariate binary logistic regression analysis and only variables at the $P<0.05$ significance levels were included in multivariate analysis. Analysis was performed with the use of SPSS software (version 19; SPSS Inc., Chicago, IL).

\section{Results}

In total, one hundred and four adult patients with critical illness (medical $n=44$, surgical $\mathrm{n}=60$ ) admitted to Glasgow Royal Infirmary ICU in the period between September 2006 to March 2008 were studied. The characteristics of the patients with critical illness on admission are shown in Table 1. The majority of patients were male (69\%) and had median age of 61 years. The median APACHE II score was 21 , predicted hospital mortality rate was $39 \%$ and SOFA score was 7 . All patients had sepsis and in particular, 10 and 5 patients were treated for severe sepsis and septic shock respectively. Compared with controls $(n=86)$, patients with critical illness had lower median arginine and homoarginine concentrations and higher ADMA and SDMA concentrations (all $p<$ 0.001). Also, critically ill patients had lower ADMA: SDMA and arginine: ADMA ratios and higher total dimethylarginine (sum of ADMA and SDMA) concentrations (both $p<0.001$ ).

The relationship between patient characteristics, plasma ADMA concentrations, other parameters and ICU death is shown in Table 2. Non-survivors had significantly higher SOFA scores ( $p$ $<0.001$ ), higher ADMA, SDMA and total dimethylarginine concentrations (all $p<0.05$ ), lower homoarginine concentrations $(p<0.028)$ and lower albumin concentrations $(p<0.017)$. They also had a longer ICU length of stay $(p<0.001)$.

Univariate and multivariate binary logistic regression analysis of clinical characteristics and dimethylarginine concentrations on admission to ICU and ICU death in critically ill patients is shown in Table 3. On univariate binary logistic regression analysis of the significant parameters identified in 
comparison of survivors and non-survivors, only SOFA scores $(p<0.01)$, ICU length of stay $(p<0.01)$, homoarginine $(p<0.05), \operatorname{ADMA}(p<0.01)$, ADMA+SDMA $(p<0.05)$ and daily fluid balance were significantly associated with ICU mortality. On multivariate binary logistic regression analysis of these significant parameters, only SOFA score $(p<0.01)$ was independently associated with ICU mortality. When SOFA score was removed from the multivariate analysis only ADMA (OR=23.7, $p<0.01)$ and ICU length of stay $(O R=1.04, p<0.01)$ were independently associated with ICU mortality.

Of the 104 patients who were admitted into the ICU, 33 patients had a second blood sample measurement of plasma ADMA concentrations (Table 4) prior to discharge $(n=17)$ or death $(n=16)$. The remaining patients did not have a blood sample due to discharge $(n=61)$ or death $(n=10)$. The former patients spent longer in ICU (median 16 days) than the latter patients (median 3 days) and therefore were more likely to have a second blood sample. The median time between admission and the last sample was 7 (range 5-15, IQR 6-8) days. There was a significant decrease in SOFA score $(p<0.02)$, arginine $(p<0.008)$, homoarginine $(p<0.001)$, ALT $(p<0.012)$, Lab-Glucose $(p<0.012)$, and albumin $(p<0.012)$. There was a significant increase in ADMA $(p<0.009)$, ADMA: SDMA ratio $(p<$ $0.003)$, and the administration of norepinephrine $(p<0.017)$.

\section{Discussion}

Plasma dimethylarginines, especially ADMA, have been previously reported to be associated with mortality in critically ill patients, and have been speculated to be a cause of endothelial dysfunction and multiple organ failure in this patient group [1;13;14;22]. In the present study it was shown that plasma concentrations of ADMA and SDMA were significantly higher in critically ill patients compared with healthy controls and that both were significantly associated with disease severity and mortality. The strength of association between ADMA and mortality was striking (odds ratio 30 and was directly associated with organ dysfunction (SOFA), most closely associated with mortality [13]. When SOFA scores were removed from the analysis, the admission ADMA was independently associated with ICU mortality. This association supports the hypothesis that ADMA metabolism may play a causative role in endothelial dysfunction through impairment of NOS activity. However, further studies of ADMA metabolism are warranted in patients with critical illness.

Homoarginine is an amino acid largely generated from lysine and may promote endothelial function as a substrate for NO synthesis [23], although it may be present at too low a concentration for this to be important, given the relative concentration of arginine is about 30 times greater [21]. A potentially more important role that has received some attention is in the inhibition of the enzyme arginase with consequent preservation of arginine for NOS [24]. Indeed, low homoarginine concentrations have been recently shown to be associated with mortality and cardiovascular events [25]. Furthermore, increased homoarginine concentrations during normal pregnancy are associated with increases in brachial artery diameter and flow-mediated dilatation [26]. In the present study, homoarginine was positively associated with arginine $\left(r_{s}=0.641, p<0.001\right)$, consistent with the above concept. Indeed, homoarginine was significantly inversely associated with C-reactive protein $\left(r_{s}=-0.349, p=0.001\right)$ suggesting an effect of inflammation on homoarginine synthesis and/or metabolism.

This article is protected by copyright. All rights reserved. 
In the present study SDMA was also associated with increased mortality. However, there was a strong association between SDMA and creatinine concentrations on admission ( $n=104, r_{s}=$ $0.62, p<0.001)$ and on follow-up $\left(n=60, r_{s}=0.76, p<0.001\right)$ and therefore plasma SDMA concentrations, in the main, reflect renal function, which is perhaps not surprising given that its main route elimination is renal. It has previously been speculated that by competing with arginine uptake at cationic amino acid transporters (CAT) SDMA can impair the delivery of the substrate arginine to NOS [27]. However, it has not been established whether the concentrations encountered in vivo are sufficient to have a significant effect. Therefore, it may be that the association of SDMA with mortality simply reflects the effect of renal impairment.

ADMA and SDMA are generated by the methylation of arginine residues in proteins by type 1 protein arginine methyltransferases (type 1 PRMTs) and from type 2 protein arginine methyl transferases (type 2 PRMTs) respectively. Daily production of ADMA is approximately $300 \mu \mathrm{mol}$ with about $10 \%$ of this amount excreted unchanged into the urine. The majority is metabolized by dimethylarginine dimethylaminohydrolase (DDAH) to citrulline and dimethylamine. In contrast, SDMA is mainly excreted unchanged in urine and is increasingly being regarded as a sensitive marker of renal function [11;28].

In the present study the ADMA: SDMA ratio was significantly lower in critically-ill patients compared with controls. The ADMA: SDMA ratio has previously been shown to be reduced in patients with acute infections, severe sepsis, post-operatively and in rats following lipopolysaccharide administration; it has been speculated that the reduction in ratio reflects an inflammation-induced increase in ADMA clearance through DDAH activity [13;29-31]. However, in no such study has DDAH activity in vivo been assessed, and therefore no conclusion can be reached about this at the present time; indeed in the present study there was no direct association between CRP and ADMA concentration. Inflammatory cytokines have been shown to both increase and decrease DDAH activity in different models [32;33], but the net effect in vivo, taking into account the confounding effects of oxidative stress and NO itself, is unclear.

A novel aspect of the present study was the longitudinal measurement of ADMA metabolism. In the present study approximately one third of patients had follow-up analysis. The mortality was greater in those patients with a follow-up sample compared to those who did not (48\% vs 25\%). Moreover, length of ICU stay was greater in this group (median 16 days vs 3 days). Therefore, this subsample is likely to represent a group of sicker patients. Nevertheless, the ADMA and arginine concentrations increased on subsequent sampling whereas SOFA scores, homoarginine and glucose concentrations fell. In contrast, C-reactive protein concentrations were not altered. Therefore, from these results and from the foregoing discussion it is clear ADMA metabolism in the patient with critical illness is complex. However, a similar pattern has been reported in patients undergoing elective surgery who had a significant inflammatory response, although in those patients this was following a significant reduction in ADMA concentration from baseline [18]. In these patients there was no change in SDMA concentrations, indicating differential handling of the dimethylarginines. However, there was no clear evidence of increased ADMA metabolism, and it may be have been that ADMA transport via CATs was the more important factor [18;34]. This is an area which is worthy of further study in critical illness, as it is becoming clear that the plasma concentrations may not reflect the pathophysiologically important tissue concentrations, which even in health are up to $10-20$ times that found in plasma [2;32].

This article is protected by copyright. All rights reserved. 
There are two distinct isoforms of DDAH. DDAH-1 is widely expressed, particularly in tissues such as liver, renal cortex, lung and immune tissues and cells. There are large arterio-venous gradients across organs such as the liver and kidney, and DDAH-1 has been described as the "guardian" of circulating ADMA concentration [35]. In contrast, DDAH-2 is mainly found in tissues which express endothelial nitric oxide synthase (eNOS) and inducible nitric oxide synthase (iNOS) such as endothelium and smooth muscle cells of cardiovascular system [36;37]. As such, DDAH-2 appear to be more involved in the regulation of local endothelial responses [35]. Consequently, ADMA concentrations in plasma are regulated within fairly narrow limits in health, and it is clear that DDAH-mediated metabolism is the critical step in this regulation [37;38].

The activity of dimethylaminohydrolase (DDAH) is highly dependent on a cysteine residue at its catalytic site. This is susceptible to oxidation as a consequence of oxidative stress and may provide a mechanism that results in increased ADMA concentration and reduced NO formation [37]. This has been observed with hyperglycaemia and hyperhomocystinaemia [37]. Therefore, interaction between dimethylaminohydrolase (DDAH), ADMA and NOS may present a common pathway of several risk factors affecting the vascular endothelium.

Indeed, a recent study in critically ill rabbits showed that tissue DDAH activity was a stronger determinant of plasma than tissue ADMA concentration, suggesting that CAT-mediated exchange of ADMA between compartments might be even more important than changes in DDAH activity itself [39]. Previous work has documented increased fractional excretion of ADMA by the liver during endotoxaemia [30], but, again, this does not differentiate between an increase in CAT-mediated uptake and a true increase in DDAH activity itself. In this regard, it has also been shown that methylarginine uptake into endothelial cells and macrophages increases with cytokine stimulation [34]. With current limitations in knowledge, caution should be exercised when interpreting the ADMA: SDMA ratio that might not be useful as a simple surrogate marker of DDAH activity for these reasons.

Limitations of the present study were principally that it was a single centre study and there was no validation cohort. The cohort was a mix of surgical and medical patients and there was considerable variation in the severity of illness. Furthermore, there were significant attrition of patients on follow up and this limits interpretation of the data and the conclusions that can be reached.

In summary, plasma ADMA and SDMA concentrations were higher in patients with critical illness and were associated with disease severity and mortality. In contrast, plasma homoarginine concentrations were lower in patients with critical illness and were also associated with disease severity and mortality. These results suggest that ADMA metabolism is perturbed with likely knock on effects on NOS and endothelial function. There is a need for further work on in vivo DDAH activity in critical illness and the effect of critical illness on the CAT-mediated exchange of ADMA between intra and extra-cellular compartments.

This article is protected by copyright. All rights reserved. 
Conflict of interest statement: None of the authors had personal or financial conflicts of interest.

Ethical approval: The study was approved by the ethics committees of the North Glasgow NHS Trust and Multicentre Research Ethics Committee (MREC) Scotland. Where patients were unable to give signed informed consent, consent was obtained from the patients' next of kin or welfare guardian in accordance with the requirements of the Adults with Incapacity Scotland (2000) Act.

Authors' contributions: The author's responsibilities were as follows- DT, JK and DCM conceived the idea and funded the study; RG and SR carried out the laboratory analysis of the blood samples; clinical information was collected by RG, LW and JK; RG and DCM performed the statistical analysis; all authors contributed to the drafts and final version of the paper and are the guarantors.

Acknowledgements: The authors gratefully acknowledge funding from Libyan government and the assistance of Dr. Malcolm Daniel Consultant in anaesthesia and intensive care, Glasgow Royal Infirmary

Reference List

[1] Siroen MPC, van Leeuwen PAM, Nijveldt RJ, Teerlink T, Wouters PJ, Van den Berghe G. Modulation of asymmetric dimethylarginine in critically ill patients receiving intensive insulin treatment: A possible explanation of reduced morbidity and mortality? Critical Care Medicine 2005; 33: 504-510.

[2] Teerlink T, Luo Z, Palm F, Wilcox CS. Cellular ADMA: Regulation and action. Pharmacological Research 2009; 60: 448-460.

[3] Van den Berghe G, Wilmer A, Milants I, Wouters PJ, Bouckaert B, Bruyninckx F, Bouillon R, Schetz $M$. Intensive insulin therapy in mixed medical/surgical intensive care units - Benefit versus harm. Diabetes 2006; 55: 3151-3159.

[4] Ellger B, Richir MC, Van Leeuwen PA, Debaveye Y, Langouche L, Vanhorebeek I, Teerlink T, Van den Berghe G. Glycemic control modulates arginine and asymmetrical-dimethylarginine levels during critical illness by preserving dimethylarginine-dimethylaminohydrolase activity. Endocrinology 2008; 149: 3148-3157.

[5] Nijveldt RJ, Teerlink T, van der Hoven B, Siroen MPC, Kuik DJ, Rauwerda JA, van Leeuwen PAM. Asymmetrical dimethylarginine (ADMA) in critically ill patients: high plasma ADMA concentration is an independent risk factor of ICU mortality. Clinical Nutrition 2003; 22: 2330.

[6] Siervo M, Corander M, Stranges S, Bluck L. Post-challenge hyperglycaemia, nitric oxide production and endothelial dysfunction: The putative role of asymmetric dimethylarginine (ADMA). Nutrition Metabolism and Cardiovascular Diseases 2011; 21: 1-10.

[7] Blackwell S. The biochemistry, measurement and current clinical significance of asymmetric dimethylarginine. Annals of Clinical Biochemistry 2010; 47: 17-28.

This article is protected by copyright. All rights reserved. 
[8] Boeger RH, Sullivan LM, Schwedhelm E, Wang TJ, Maas R, Benjamin EJ, Schulze F, Xanthakis $\mathrm{V}$, Benndorf RA, Vasan RS. Plasma Asymmetric Dimethylarginine and Incidence of Cardiovascular Disease and Death in the Community. Circulation 2009; 119: 1592-1U65.

[9] Siervo M, Corander M, Stranges S, Bluck L. Post-challenge hyperglycaemia, nitric oxide production and endothelial dysfunction: The putative role of asymmetric dimethylarginine (ADMA). Nutrition Metabolism and Cardiovascular Diseases 2011; 21: 1-10.

[10] Nijveldt RJ, Teerlink T, van der Hoven B, Siroen MPC, Kuik DJ, Rauwerda JA, van Leeuwen PAM. Asymmetrical dimethylarginine (ADMA) in critically ill patients: high plasma ADMA concentration is an independent risk factor of ICU mortality. Clinical Nutrition 2003; 22: 2330.

[11] Can A, Bekpinar S, Gurdol F, Tutuncu Y, Unlucerci Y, Dinccag N. Dimethylarginines in patients with type 2 diabetes mellitus: Relation with the glycaemic control. Diabetes Research and Clinical Practice 2011; 94: E61-E64.

[12] Davis JS, Darcy CJ, Yeo TW, Jones C, McNeil YR, Stephens DP, Celermajer DS, Anstey NM. Asymmetric Dimethylarginine, Endothelial Nitric Oxide Bioavailability and Mortality in Sepsis. Plos One 2011; 6.

[13] Iapichino G, Umbrello M, Albicini M, Spanu P, Bellani G, Polli F, Pavlovic R, Cugno M, Fermo I, Paroni R. Time course of endogenous nitric oxide inhibitors in severe sepsis in humans. Minerva Anestesiologica 2010; 76: 325-333.

[14] Nijveldt RJ, Teerlink T, van der Hoven B, Siroen MPC, Kuik DJ, Rauwerda JA, van Leeuwen PAM. Asymmetrical dimethylarginine (ADMA) in critically ill patients: high plasma ADMA concentration is an independent risk factor of ICU mortality. Clinical Nutrition 2003; 22: 2330.

[15] Schuetz P, Friedli N, Grolimmund E, Kutz A, Haubitz S, Christ-Crain M, Thomann R, Zimmerli W, Hoess C, Henzen C, Mueller B. Effect of hyperglycaemia on inflammatory and stress responses and clinical outcome of pneumonia in non-critical-care inpatients: results from an observational cohort study. Diabetologia 2014; 57: 275-284.

[16] Siroen MPC, van Leeuwen PAM, Nijveldt RJ, Teerlink T, Wouters PJ, van den Berghe G. Modulation of asymmetric dimethylarginine in critically ill patients receiving intensive insulin treatment: A possible explanation of reduced morbidity and mortality? Critical Care Medicine 2005; 33: 504-510.

[17] lapichino G, Albicini M, Umbrello M, Sacconi F, Fermo I, Pavlovich R, Paroni R, Bellani G, Mistraletti G, Cugno M, Pesenti A, Gattinoni L. Tight glycemic control does not affect asymmetric-dimethylarginine in septic patients. Intensive Care Medicine 2008; 34: 18431850.

[18] Blackwell S, O'Reilly DS, Reid D, Talwar D. Plasma dimethylarginines during the acute inflammatory response. European Journal of Clinical Investigation 2011; 41: 635-641.

[19] Bone RC, Balk RA, Cerra FB, Dellinger RP, Fein AM, Knaus WA, Schein RMH, Sibbald WJ. Definitions for Sepsis and Organ Failure and Guidelines for the Use of Innovative Therapies in Sepsis. Chest 1992; 101: 1644-1655.

[20] Levy MM, Fink MP, Marshall JC, Abraham E, Angus D, Cook D, Cohen J, Opal SM, Vincent JL,

This article is protected by copyright. All rights reserved. 
Ramsay G. 2001 Sccm/Esicm/Accp/Ats/Sis International Sepsis Definitions Conference. Critical Care Medicine 2003; 31: 1250-1256.

[21] Blackwell S, O'Reilly DS, Talwar DK. HPLC analysis of asymmetric dimethylarginine (ADMA) and related arginine metabolites in human plasma using a novel non-endogenous internal standard. Clinica Chimica Acta 2009; 401: 14-19.

[22] Nijveldt RJ, Teerlink T, van Leeuwen PAM. The assymmetrical dimethylarginine (ADMA)multiple organ failure hypothesis. Clinical Nutrition 2003; 22: 99-104.

[23] Hecker M, Walsh DT, Vane JR. On the Substrate-Specificity of Nitric-Oxide Synthase. Febs Letters 1991; 294: 221-224.

[24] Yang Z, Ming XF. Endothelial arginase: A new target in atherosclerosis. Current Hypertension Reports 2006; 8: 54-59.

[25] Maerz W, Meinitzer A, Drechsler C, Pilz S, Krane V, Kleber ME, Fischer J, Winkelmann BR, Boehm BO, Ritz E, Wanner C. Homoarginine, Cardiovascular Risk, and Mortality. Circulation 2010; 122: 967-975.

[26] Valtonen P, Laitinen T, Lyyra-Laitinen T, Raitakari OT, Juonala M, Viikari JS, Heiskanen N, Vanninen E, Punnonen K, Heinonen S. Serum L-Homoarginine Concentration is Elevated During Normal Pregnancy and is Related to Flow-Mediated Vasodilatation. Circulation Journal 2008; 72: 1879-1884.

[27] Closs El, Basha FZ, Habermeier A, Forstermann U. Interference of L-arginine analogues with L-arginine transport mediated by the $\mathrm{y}(+)$ carrier hCAT-2B. Nitric Oxide-Biology and Chemistry 1997; 1: 65-73.

[28] Kielstein JT, Martens-Lobenhoffer J, Vollmer S, Bode-Boeger SM. L-Arginine, ADMA, SDMA, creatinine, MDRD formula: detour to renal function testing. Journal of Nephrology 2008; 21: 959-961.

[29] Blackwell S, O'Reilly DS, Reid D, Talwar D. Plasma dimethylarginines during the acute inflammatory response. European Journal of Clinical Investigation 2011; 41: 635-641.

[30] Nijveldt RJ, Siroen MPC, Teerlink T, van Lambalgen AA, Rauwerda JA, van Leeuwen PAM. Gut and liver handling of asymmetric and symmetric dimethylarginine in the rat under basal conditions and during endotoxemia. Liver International 2004; 24: 510-518.

[31] Zoccali C, Maas R, Cutrupi S, Pizzini P, Finocchiaro P, Cambareri F, Panuccio V, Martorano C, Schulze F, Enia G, Tripepi G, Boger R. Asymmetric dimethyl-arginine (ADMA) response to inflammation in acute infections. Nephrology Dialysis Transplantation 2007; 22: 801-806.

[32] Cardounel AJ, Cui H, Samouilov A, Johnson W, Kearns P, Tsai AL, Berka V, Zweier JL. Evidence for the pathophysiological role of endogenous methylarginines in regulation of endothelial NO production and vascular function. Journal of Biological Chemistry 2007; 282: 879-887.

[33] Ueda S, Kato S, Matsuoka H, Kimoto M, Okuda S, Morimatsu M, Imaizumi T. Regulation of cytokine-induced nitric oxide synthesis by asymmetric dimethylarginine - Role of dimethylarginine dimethylaminohydrolase. Circulation Research 2003; 92: 226-233.

[34] Teerlink T, Luo Z, Palm F, Wilcox CS. Cellular ADMA: Regulation and action. Pharmacological

This article is protected by copyright. All rights reserved. 
Research 2009; 60: 448-460.

[35] Palm F, Onozato ML, Luo Z, Wilcox CS. Dimethylarginine dimethylaminohydrolase (DDAH): expression, regulation, and function in the cardiovascular and renal systems. American Journal of Physiology-Heart and Circulatory Physiology 2007; 293: H3227-H3245.

[36] Li N, Worthmann H, Deb M, Chen S, Weissenborn K. Nitric oxide (NO) and asymmetric dimethylarginine (ADMA): their pathophysiological role and involvement in intracerebral hemorrhage. Neurological Research 2011; 33: 541-548.

[37] Blackwell S. The biochemistry, measurement and current clinical significance of asymmetric dimethylarginine. Annals of Clinical Biochemistry 2010; 47: 17-28.

[38] Teerlink T. ADMA metabolism and clearance. Vascular Medicine 2005; 10: S73-S81.

[39] Davids M, Richir MC, Visser M, Ellger B, Van den Berghe G, Van Leeuwen PA, Teerlink T. Role of dimethylarginine dimethylaminohydrolase activity in regulation of tissue and plasma concentrations of asymmetric dimethylarginine in an animal model of prolonged critical illness. Metabolism-Clinical and Experimental 2012; 61: 482-490.

\section{Abbreviations}

ICU: Intensive Care Unit.

Lab-Glucose: Laboratory Glucose.

CRP: C-reactive protein.

ALT: aminotransferase.

NOS: nitric oxide synthase.

APACHE II: Acute physiology and Chronic Health Evaluation II score.

SOFA: Sequential Organ Failure Assessment.

HPLC: high-performance liquid chromatography.

$\mathrm{CV}$ : coefficients of variation.

ADMA: Asymmetrical Dimethylarginine.

SDMA: Symmetrical Dimethylarginine.

DDAH: dimethylarginine dimethylaminohydrolase.

CAT: cationic amino acid transporters.

IQR: interquartile range

Figure 1: Interactions between oxidative stress, dimethylarginine dimethylaminohydrolase (DDAH), asymmetric dimethylarginine (ADMA) and nitric oxide synthase (NOS). SDMA, symmetric dimethylarginine; PRMTs, protein arginine methyltransferases; TNF-a, tumour necrosis factor-a (Blackwell, 2010)

This article is protected by copyright. All rights reserved. 


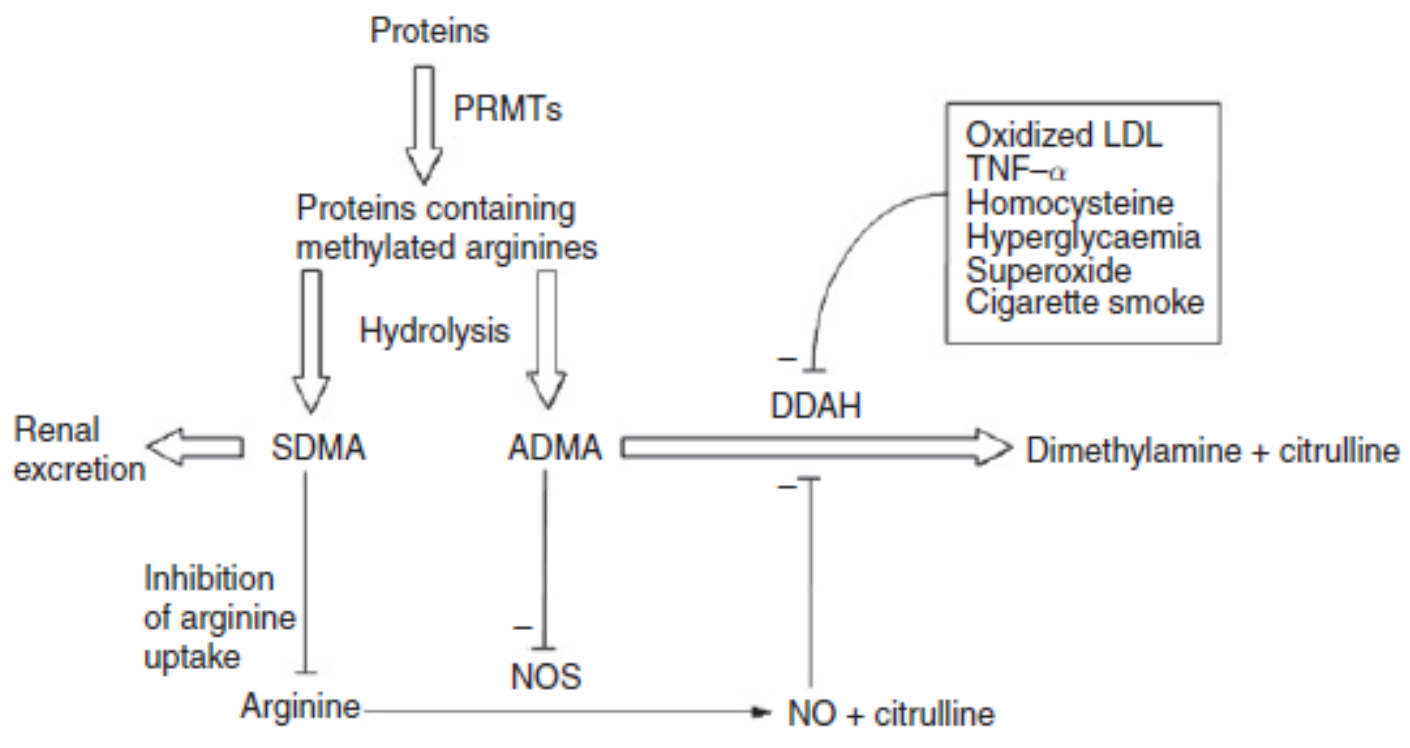

\section{Tables legends}

Table 1. Admission characteristics and arginine, homoarginine, ADMA and SDMA concentrations in normal subjects and critically-ill patients $(n=104)$.

Table 2 Admission patient characteristics and measurements between survivors and non-survivors $(n=104)$.

Table 3. The relationship between clinical characteristics and ADMA on admission to ICU mortality in patients with critical illness. Univariate and multivariate binary logistic regression analysis.

Table 4. The relationship between patient characteristics and plasma arginine, homoarginine, ADMA, and SDMA concentrations in critically-ill patients on admission and (follow-up) last sample median day 7 (range 5-15) (IQR 6-8)

This article is protected by copyright. All rights reserved. 
Table 1. Admission characteristics and arginine, homoarginine, ADMA and SDMA concentrations in normal subjects and critically-ill patients $(n=104)$.

\begin{tabular}{|c|c|c|c|}
\hline & $\begin{array}{l}\text { Reference Intervals } \\
\text { (Control) }(\mathrm{n}=86)\end{array}$ & $\begin{array}{l}\text { Patients with critical } \\
\text { illness }(\mathrm{n}=104)\end{array}$ & P-value* \\
\hline Age (Year) & $43(20-65)$ & $61(47-71)$ & \\
\hline Gender (Male/Female) (\%) & $44(51) / 42(49)$ & $72(69) / 32(31)$ & \\
\hline Admission cause (Surgical/Medical) (\%) & & $60(58) / 44(42)$ & \\
\hline APACHE II & & $21(17-27)$ & \\
\hline Predicted mortality rate $(\%)$ & & $38.9(17.6-60.4)$ & \\
\hline SOFA score & & $7.0(4.0-9.0)$ & \\
\hline Severe sepsis/septic shock (\%) & & $10(10) / 5(5)$ & \\
\hline Arginine $\left(\mu \mathrm{mol} \mathrm{L}^{-1}\right)$ & $65.7(48.8-79.9)$ & $18.4(12.9-29.1)$ & $<0.001$ \\
\hline Homoarginine $\left(\mu \mathrm{mol} \mathrm{L}^{-1}\right)$ & $1.90(1.38-2.49)$ & $0.58(0.32-1.18)$ & $<0.001$ \\
\hline $\operatorname{ADMA}\left(\mu \mathrm{mol} \mathrm{L}^{-1}\right)$ & $0.45(0.41-0.52)$ & $0.54(0.41-0.64)$ & $<0.001$ \\
\hline SDMA $\left(\mu \mathrm{mol} \mathrm{L}^{-1}\right)$ & $0.38(0.34-0.43)$ & $0.75(0.52-1.15)$ & $<0.001$ \\
\hline ADMA/SDMA ratio & $1.20(1.10-1.36)$ & $0.73(0.43-1.02)$ & $<0.001$ \\
\hline Arginine/ADMA ratio & $125.7(101.0-171.5)$ & $36.7(26.0-56.6)$ & $<0.001$ \\
\hline Total dimethylarginine $\left(\mu \mathrm{mol} \mathrm{L}^{-1}\right)$ & $0.82(0.76-0.88)$ & $1.2(1.0-1.83)$ & $<0.001$ \\
\hline Creatinine (umol/L) ${ }^{\S}$ & $68-118$ & $117(78-171)$ & \\
\hline Total Bilirubin (umol/l) $)^{\S}$ & $5.1-17.0$ & $10.5(7.0-21.0)$ & \\
\hline $\operatorname{ALT}(\mathrm{U} / \mathrm{L})^{\S}$ & $10-40$ & $37(18-115)$ & \\
\hline Lab-Glucose $(\mathrm{mmol} / \mathrm{l})^{\S}$ & $3.5-5.5$ & $6.4(5.5-8.1)$ & \\
\hline C-reactive protein $(\mathrm{mg} / \mathrm{l})^{\S}$ & $<10$ & $119(41-216)$ & \\
\hline White cell count $\left(10^{9} / \mathrm{L}\right)^{\S}$ & $4-11 \times 10^{9}$ & $11.4(7.9-18.5)$ & \\
\hline Albumin $(\mathrm{g} / \mathrm{l})^{\S}$ & $35-55$ & $16(12-21)$ & \\
\hline Daily fluid balance (ml) & & $1034(393-2343)$ & \\
\hline Insulin $\left(\mathrm{U}_{\text {hour }}{ }^{-1}\right)^{\frac{7}{7}}$ & & $0.9(0.0-9.3)$ & \\
\hline Norepinephrine $\left(\mathrm{mg} \text { hour }{ }^{-1}\right)^{\frac{1}{7}}$ & & $0.5(0.0-6.0)$ & \\
\hline Epinephrine $\left(\mathrm{mg} \text { hour }{ }^{-1}\right)^{\frac{7}{7}}$ & & $0.1(0.0-2.7)$ & \\
\hline Dobutamine $\left(\mathrm{mg} \text { hour }{ }^{-1}\right)^{\frac{\hbar}{7}}$ & & $2.5(0.0-76.4)$ & \\
\hline Hydrocortisone $\left(\mathrm{mg} \mathrm{hour}^{-1}\right)^{\ddagger}$ & & $1.9(0.0-16.0)$ & \\
\hline ICU length of stay (Days) & & $5.1(2.0-13.6)$ & \\
\hline ICU death No/Yes & & $78(75 \%) / 26(25 \%)$ & \\
\hline
\end{tabular}

Median (interquartile range, IQR), ${ }^{8}$ reference interval, ${ }^{\ddagger}$ Mean (range), * Mann-Whitney $U$.

This article is protected by copyright. All rights reserved. 
Table 2 Admission patient characteristics and measurements between survivors and nonsurvivors $(\mathrm{n}=104)$.

\begin{tabular}{|c|c|c|c|}
\hline & $\begin{array}{l}\text { Admission Survivors } \\
(\mathrm{n}=78)\end{array}$ & $\begin{array}{l}\text { Admission Non-survivors } \\
(\mathrm{n}=26)\end{array}$ & P-value* \\
\hline Age (Year) & $60(43-69)$ & $67(48-74)$ & 0.175 \\
\hline Gender (Male/Female) (\%) & $55(71) / 23(29)$ & $17 / 9$ & 0.625 \\
\hline Admission cause (Surgical/Medical) (\%) & $45(58) / 33(42)$ & $15 / 11$ & 1.000 \\
\hline APACHE II & $21(16-26)$ & $24(18-31)$ & 0.174 \\
\hline Predicted mortality rate $(\%)$ & $35.3(14.1-57.3)$ & $45.6(23.3-73.8)$ & 0.061 \\
\hline SOFA score & $5(4-8)$ & $8(7-11)$ & 0.001 \\
\hline Severe sepsis/septic shock (\%) & $7(9) / 5(6)$ & $3(12) / 0(0)$ & \\
\hline Arginine $\left(\mu \mathrm{mol} \mathrm{L}^{-1}\right)$ & $17.5(12.1-29.0)$ & $19.6(17.3-34.9)$ & 0.281 \\
\hline Homoarginine $\left(\mu \mathrm{mol} \mathrm{L}^{-1}\right)$ & $0.70(0.35-1.30)$ & $0.50(0.26-0.77)$ & 0.028 \\
\hline $\operatorname{ADMA}\left(\mu \mathrm{mol} \mathrm{L}^{-1}\right)$ & $0.49(0.38-0.62)$ & $0.59(0.52-0.90)$ & 0.003 \\
\hline SDMA $\left.(\mu \mathrm{mol} \mathrm{L})^{-1}\right)$ & $0.69(0.50-1.10)$ & $0.94(0.57-1.72)$ & 0.047 \\
\hline ADMA/SDMA ratio & $0.72(0.43-1.02)$ & $0.79(0.37-1.05)$ & 0.866 \\
\hline Arginine/ADMA ratio & $38.5(25.7-59.2)$ & $33.3(26.0-49.2)$ & 0.218 \\
\hline Total dimethylarginine $\left(\mu \mathrm{mol} \mathrm{L} \mathrm{L}^{-1}\right)$ & $1.2(0.92-1.68)$ & $1.7(1.2-2.5)$ & 0.008 \\
\hline eGFR $>30 / \leq 30$ & $10(0-35)$ & $11(0-28)$ & 0.747 \\
\hline Creatinine (umol/L) & $115(73-169)$ & $118(79-249)$ & 0.605 \\
\hline Total Bilirubin $(\mu \mathrm{mol} / \mathrm{l})$ & $10.5(8-20)$ & $10.5(7-28)$ & 0.980 \\
\hline ALT & $38.5(19-129)$ & $37(15-115)$ & 0.556 \\
\hline Lab-Glucose $(\mathrm{mmol} / \mathrm{l})$ & $6.4(5.5-8.1)$ & $6.8(5.4-9.2)$ & 0.642 \\
\hline C-reactive protein $(\mathrm{mg} / \mathrm{l})$ & $108(40-218)$ & $125(42-169)$ & 0.870 \\
\hline White cell count $\left(10^{9} / \mathrm{L}\right)$ & $10.8(7.6-16.9)$ & $16.3(7.9-20.0)$ & 0.223 \\
\hline Albumin $(\mathrm{g} / \mathrm{l})$ & $17(13-23)$ & $13(10-19)$ & 0.017 \\
\hline Daily fluid balance (ml) & $1006(393-2166)$ & $4793(-7-5113)$ & 0.167 \\
\hline Insulin $\left(\mathrm{U} \text { hour }^{-1}\right)^{\ddagger}$ & $0.9(0.0-9.3)$ & $0.7(0.0-4.8)$ & 0.874 \\
\hline Norepinephrine (mg hour-1) & $0.4(0.0-2.5)$ & $0.8(0.0-6.0)$ & 0.292 \\
\hline Epinephrine $\left(\mathrm{mg} \mathrm{hour}^{-1}\right)^{\ddagger}$ & $0.1(0.0-2.7)$ & $0.1(0.0-1.0)$ & 0.894 \\
\hline Dobutamine $\left(\mathrm{mg} \mathrm{hour}^{-1}\right)^{\frac{7}{7}}$ & $2.4(0.0-76.4)$ & $2.7(0.0-50.0)$ & 0.431 \\
\hline Hydrocortisone (mg hour-1) & $2.2(0.0-16.0)$ & $1.2(0.0-8.0)$ & 0.276 \\
\hline ICU length of stay (Days) & $3(1-10)$ & $11.6(6-19)$ & $<0.001$ \\
\hline
\end{tabular}

Median (interquartile range, IQR), ${ }^{\ddagger}$ Mean (range), * Mann-Whitney $U$.

This article is protected by copyright. All rights reserved. 
Table 3. The relationship between clinical characteristics and ADMA on admission to ICU mortality in patients with critical illness. Univariate and multivariate binary logistic regression analysis.

\begin{tabular}{|c|c|c|c|c|}
\hline & $\begin{array}{l}\text { Univariate analysis } \\
\text { OR }(95 \% \mathrm{CI})\end{array}$ & $\mathrm{P}$-value & $\begin{array}{l}\text { Multivariate analysis } \\
\text { OR }(95 \% \mathrm{CI})\end{array}$ & P-value \\
\hline Age (years) & $1.02(0.99-1.05)$ & 0.292 & & \\
\hline Sex (male/female) & $1.27(0.49-3.25)$ & 0.624 & & \\
\hline Patients (medical/surgical) & $1.00(0.41-2.46)$ & 1.000 & & \\
\hline APACHE II score & $1.05(0.99-1.12)$ & 0.138 & & \\
\hline Predicted mortality rate $(\%)$ & $1.02(0.99-1.03)$ & 0.081 & & \\
\hline SOFA score & $1.34(1.12-1.61)$ & 0.002 & $1.053(1.104-2.120)$ & 0.011 \\
\hline ICU length of stay (days) & $1.05(1.01-1.09)$ & 0.007 & $0.951(0.097-9.323)$ & 0.965 \\
\hline Arginine $(\mu \mathrm{mol} \mathrm{L}-1)$ & $1.02(0.99-1.05)$ & 0.241 & & \\
\hline Homoarginine $(\mu \mathrm{mol} \mathrm{L}-1)$ & $0.39(0.15-0.99)$ & 0.048 & $0.545(0.105-2.837)$ & 0.471 \\
\hline $\mathrm{ADMA}(\mu \mathrm{mol} \mathrm{L}-1)$ & $31.31(3.34-293.18)$ & 0.003 & $0.793(0.003-218.189)$ & 0.936 \\
\hline SDMA $(\mu \mathrm{mol}$ L-1) & $1.54(0.90-2.64)$ & 0.118 & & \\
\hline ADMA/SDMA ratio & $1.10(0.30-4.06)$ & 0.887 & & \\
\hline Arginine/ADMA ratio & $0.99(0.97-1.01)$ & 0.243 & & \\
\hline ADMA+SDMA & $1.66(1.02-2.70)$ & 0.041 & $2.653(0.090-78.137$ & 0.572 \\
\hline eGFR $>30 /<30$ & $0.99(0.97-1.02)$ & 0.771 & & \\
\hline Creatinine umol/L & $1.00(0.99-1.00)$ & 0.721 & & \\
\hline Bilirubin (umol/l) & $1.00(0.99-1.01)$ & 0.858 & & \\
\hline $\operatorname{ALT}(\mathrm{u} / \mathrm{l})$ & $1.00(1.00-1.00)$ & 0.661 & & \\
\hline Lab-Glucose mmol/l & $1.05(0.94-1.16)$ & 0.413 & & \\
\hline C-reactive protein $(\mathrm{mg} / \mathrm{l})$ & $1.00(0.99-1.01)$ & 0.665 & & \\
\hline Albumin $(\mathrm{g} / \mathrm{l})$ & $0.92(0.85-1.00)$ & 0.063 & & \\
\hline Daily fluid balance (ml) & $1.00(1.00-1.00)$ & 0.020 & $1.000(1.000-1.001)$ & 0.427 \\
\hline Insulin (U hour -1) & $0.93(0.70-1.24)$ & 0.623 & & \\
\hline Norepinephrine (mg hour-1) & $1.51(0.95-2.40)$ & 0.079 & & \\
\hline Epinephrine (mg hour-1) & $0.89(0.25-3.23)$ & 0.864 & & \\
\hline Dobutamine (mg hour-1) & $1.00(0.96-1.05)$ & 0.896 & & \\
\hline Hydrocortisone (mg hour-1) & $0.92(0.800-1.06)$ & 0.263 & & \\
\hline
\end{tabular}

OR, odds ratio

This article is protected by copyright. All rights reserved. 
Table 4. The relationship between patient characteristics and plasma arginine, homoarginine, ADMA, and SDMA concentrations in critically-ill patients on admission and (follow-up) last sample median day 7 (range 5-15) (IQR 6-8)

\begin{tabular}{|c|c|c|c|}
\hline & $\begin{array}{l}\text { Critically-ill patients } \\
\text { Admission }(n=33)\end{array}$ & $\begin{array}{l}\text { Critically-ill patients } \\
\text { Follow-up }(n=33)\end{array}$ & P-value* \\
\hline Age (yr) & $64(51-71)$ & & \\
\hline $\operatorname{Sex}(\mathrm{M} / \mathrm{F})(\%)$ & $23(70 \%) / 10(30 \%)$ & & \\
\hline Medical/ Surgical (\%) & $19(58 \%) / 14(42 \%)$ & & \\
\hline APACHE II score & $24(18-29)$ & & \\
\hline Predicted mortality (\%) & $46.0(21.8-71.9)$ & & \\
\hline SOFA score & $8(6-10)$ & $6(4-8)$ & 0.002 \\
\hline Severe sepsis/septic shock & $2 / 1$ & & \\
\hline Arginine $\left(\mu \mathrm{mol} \mathrm{L}^{-1}\right)$ & $19.1(12.8-31.8)$ & $24.3(21.5-35.6)$ & 0.008 \\
\hline Homoarginine $\left(\mu \mathrm{mol} \mathrm{L}{ }^{-1}\right)$ & $0.56(0.35-1.22)$ & $0.33(0.12-0.42)$ & $<0.001$ \\
\hline $\operatorname{ADMA}\left(\mu \mathrm{mol} \mathrm{L}^{-1}\right)$ & $0.60(0.50-0.84)$ & $0.71(0.57-1.04)$ & 0.009 \\
\hline SDMA $\left.(\mu \mathrm{mol} \mathrm{L})^{-1}\right)$ & $0.87(0.53-1.44)$ & $0.94(0.51-1.49)$ & 0.829 \\
\hline ADMA/SDMA ratio & $0.75(0.43-1.04)$ & $0.89(0.57-1.25)$ & 0.003 \\
\hline Arginine/ADMA ratio & $31.2(16.3-44.2)$ & $40.0(27.0-46.3)$ & 0.236 \\
\hline $\mathrm{ADMA}+\mathrm{SDMA}$ & $1.5(1.04-2.44)$ & $1.6(1.16-2.52)$ & 0.936 \\
\hline eGFR $>30 / \leq 30$ & $20.0(0.0-33.5)$ & $17.0(0.0-30.0)$ & 0.604 \\
\hline Creatinine (umol/L) & $126(93-204)$ & $167(91-278)$ & 0.626 \\
\hline Bilirubin (umol/1) & $11(7-20)$ & $11(6-27)$ & 0.350 \\
\hline $\operatorname{ALT}(\mathrm{u} / \mathrm{l})$ & $57(1-171)$ & $42(21-96)$ & 0.012 \\
\hline Lab-Glucose mmol/1 & $7.4(5.9-10.5)$ & $6.2(5.2-7.0)$ & 0.012 \\
\hline C-reactive protein $(\mathrm{mg} / \mathrm{l})$ & $72(13-156)$ & $131(56-173)$ & 0.597 \\
\hline White cell count $\left(10^{9} / \mathrm{L}\right)$ & $10.6(7.4-18)$ & $12.0(9.2-20.8)$ & 0.320 \\
\hline Albumin (g/ l) & $15(10-21)$ & $13(11-16)$ & 0.012 \\
\hline Daily fluid balance $(\mathrm{ml})$ & $469(-21-2000)$ & $1491(-275-2148)$ & 0.778 \\
\hline Insulin $\left(\text { U hour }^{-1}\right)^{\ddagger}$ & $1.0(0.0-9.3)$ & $2.1(0.0-10.9)$ & 0.148 \\
\hline Norepinephrine $\left(\mathrm{mg} \text { hour }^{-1}\right)^{\ddagger}$ & $0.4(0.0-4.0)$ & $0.5(0.0-4.4)$ & 0.017 \\
\hline Epinephrine $\left(\mathrm{mg} \mathrm{hour}^{-1}\right)^{\ddagger}$ & $0.1(0.0-2.7)$ & $0.07(0.0-1.6)$ & 0.028 \\
\hline Dobutamine $\left(\mathrm{mg} \text { hour }{ }^{-1}\right)^{\ddagger}$ & $3.9(0.0-76.4)$ & $4.5(0.0-117)$ & 0.028 \\
\hline Hydrocortisone $\left(\mathrm{mg} \text { hour }^{-1}\right)^{\ddagger}$ & $2.1(0.0-16.0)$ & $2.4(0.0-16.0)$ & 0.058 \\
\hline ICU length of stay (days) & $16(11-27)$ & & \\
\hline ICU death (no/ yes) (\%) & $17(52) / 16(48)$ & & \\
\hline
\end{tabular}

Median (interquartile range, IQR), ${ }^{\ddagger}$ Mean (range), * Wilcoxon signed rank test.

This article is protected by copyright. All rights reserved. 